\title{
Attitude of Youth to Agricultural Development Programmes In Ughelli South Local Government Area of Delta State, Nigeria
}

\author{
Ovwigho, B. $O^{1}$. and Ifie, $P \cdot A^{2}$. \\ ${ }^{1}$ Department of Agricultural Economics and Extension \\ Delta State University Asaba Campus, Delta State \\ ${ }^{2}$ Department of Agricultural Sciences Education \\ College of Education, Warri, Delta State
}

\begin{abstract}
The problems associated with youth behaviours in the Niger Delta region necessitated the study. The specific objectives were to collate the current agricultural development intervention programmes; compare the attitude of youth leaders and non-leaders to agricultural development intervention programmes, and examine the factors militating against youth involvement in agriculture. Questionnaires were used to elicit information from respondents. Simple random sampling was used to select respondents. The sample was made up of 71 youths comprising 18 leaders and 53 non-leaders. Data were analysed by the use of mean and t-test. It was found that 5 agricultural development programmes currently existed in the study area. The non-youth leaders disagreed with the 5 positive attitude statements and agreed with 4 out of the 5 negative statements. The youth leaders disagreed with 5 positive attitude statements and agreed with the 5 negative attitude statements. There was no significant difference in the mean attitude scores between youth leaders and non-leaders ( $t=0.05 ; p>0.05)$. The factors militating against youth involvement in agriculture were lack of basic infrastructure $(\bar{x}=2.62)$, lack of modern agricultural equipment ( $\bar{x}=3.46)$, lack of land/land tenure system $(\bar{x}=3.34)$, lack of credit facilities $(\bar{x}=2.99)$, and poor incentives/ incomes $(\bar{x}=3.00)$. Youths should be motivated to take up agriculture through extension campaigns, and provision of inputs and land for large scale farming
\end{abstract}

\section{INTRODUCTION}

The youth phase of life is a transition between later child-hood and adult-hood characterised by the nuances of adolescence. The variegated definitions of youth encapsulate four definitional view points namely: the United Nation's definition of youth, the African definition, the religiousAfrican definition and social-personal definition (Ovwigho and Ifie, 2004). Rau and Lindley (1985), and Swanson and Claar (1984) stated that the United Nation's definition of youth included people between the age range of 15-24 years old. By this definition, it was estimated that about $20 \%$ of the world's population fell into the youth category. Age was the major criterion for differentiating youths from other members of the society as could be gleaned from the United Nations definition. 
Journal of Agricultural Extension

Vol. 13 (2) December 2009

However, in the African definition of youth, marital status and economic potentialities were the major considerations in differentiating youths from adults. Ovwigho and Ifie (2004) stated that youths were considered as people who were not yet married and depended on their parents for social and economic survival. By this definition, a 50 year old man who was not married cannot be classified as an adult even if he has a stable means of livelihood. They stated further that in the religious - African definition, youths were considered as people between the age of 15-40 years, irrespective of marital status and means of livelihood.. Even people above 40 years join youth organisations in the mosques and churches.

Closely allied to the religious-African definition is the social-personal definition. Under the social - personal definition, any person could be regarded as a youth provided he is quite sound in mind, heart and body. The proponents of this assertion are the older generation who feel that age categorisation of youth was superficial and might be devoid of the strength and agility associated with youth.

The study is targeted at youth between the age range of 15-40 years, irrespective of marital status and means of livelihood. The attitude of the youths to agricultural development intervention programmes would be measured and analysed. The Oxford Advanced Learners Dictionary defined attitude as the way one feels and thinks about something. Attitude could be described as a reaction to stimuli which is usually manifested in the form of hatred and likeness. Hate and like could be regarded as negative and positive attitudes respectively. During the pre and post-independence era, the Nigeria governments and non-governmental organizations implemented scores of agricultural development programmes ostensibly to capture the interest of youth in agriculture. The relegation of agriculture in the nation's economy and present -day youth restiveness calls for continual examination of youth interest in agriculture.

The problems associated with youth behaviors especially in the Niger Delta region have assumed an alarming proportion. According to Ovwigho (2008), new problem behaviours were being formed daily in addition to old ones. He noted that the earliest forms of youth problem behaviours, were disobedience, truancy or lying, fighting, stealing, absenteeism, cigarette smoking, alcoholism, rebelliousness, improper dressing and staying away from the home. Nowadays youth problem behaviours have metamorphosed into youth restiveness, militancy, kidnapping, hostage taking, armed robbery, burning and arson drinking of blood, cannibalism, pipe-line vanderlisation, hooliganism, cultism and gangsterism. He remarked that youth restiveness and militancy were psychological constructs used to describe the recent youth uproar particularly in the Niger Delta region. It was often characterised by the use of fire arms, hostage taking and war.

The inordinate ambition to acquire wealth is the prime cause of youth restiveness. Ovwigho (2007) stated that if ostentatious display of wealth was unchecked by the society, it could infuriate the youth and prepare the stage for youth restiveness. The youth appear to be more interested in occupations that yield quick returns. Olaitan (1984) found that many people especially the youth preferred to be distributors of farm produce rather than producers because of the long investment period. He observed that with the discovery of crude oil, the attitude of government officials and people of Nigeria changed in favour of crude oil production. Similarly Akinsanmi (1994) found that many of the youths did not show favourable attitude to the farm settlement schemes established in the 1960's and other agricultural programmess. Ovwigho (1985) stated that both the Operation Feed the Nation and Green Revolution programmess were short-lived, lacked cohesion, effective planning and execution. This study might further establish previous findings and veracity of claims about interest of youth in agriculture. 


\section{Objectives of the Study}

The general objective of the study is to evaluate the attitude of youth to agricultural development interventions. The specific objectives were to:

(i) collate the current agricultural development interventions in the study area;

(ii) ascertain the attitude of youth leaders and non-leaders to agricultural development interventions;

(iii) compare the attitude of youth leaders and non-leaders to agricultural development interventions; and

(iv) examine the factors militating against youth involvement in agriculture.

\section{METHODOLOGY}

\section{Sampling Procedure and Sample Size}

Simple random sampling techniques done on multi-stage basis was used in composing the sample. In the first stage, three (3) clans were selected out of the six clans which made up the Local Government Area. The three clans were Ewu, Ughievwen and Olomu. Five (5) percent of the towns, which corresponded to Ewu(2), Ughievwen (4) and Olomu (2), were selected. The sample consisted both youth leaders and non-leaders. This disaggregation was premised on the fact that the leaders, for example, the contact farmers interact more frequently with extension agents and were expected to show more favourable attitude to agricultural development interventions. Fifty (50) percent of youth leaders which corresponded to 18 were selected. This comprised Ewu (6), Ughievwen (8) and Olomu (4). Similarly fifty (50) percent of non-youth leaders which corresponded to 53 were selected. This comprised Ewu (15) Ughievwen (26) and Olomu (12). Thus the sample was made up of 71 youths.

\section{Instrument of Data Collection and Analysis}

Data were collected by the use of structured questionnaire. Five positive and negative statements each were constructed and administered separately to both youth leaders (Chairman and Secretary) and non-leaders. The attitude statements were measured by a 4 point rating scale. A mean score of 2.50 and above was regarded as agreed and below 2.50 as disagreed for positive statements. For negative statements, a mean score 2.50 and above was regarded as disagreed and below 2.50 as agreed. The negative statements were scored in reverse to the positive statements as shown in the following illustration.

\begin{tabular}{lcccc}
\hline & $\begin{array}{c}\text { Strongly Agree } \\
\text { (SA) }\end{array}$ & $\begin{array}{c}\text { Agree } \\
\text { (A) }\end{array}$ & $\begin{array}{c}\text { Disagree } \\
\text { (D) }\end{array}$ & $\begin{array}{c}\text { Strongly Disagree } \\
\text { (SD) }\end{array}$ \\
\hline Positive & & & & \\
Negative & 4 & 3 & 2 & 1 \\
\hline
\end{tabular}

The mean scores of youth leaders and non-leaders were compared by the use of t-test at 0.05 level of significance. 
Journal of Agricultural Extension

Vol. 13 (2) December 2009

\section{RESULTS AND DISCUSSION}

\section{Current Agricultural Development Programmes}

The agricultural development interventions found existing in the study area were the Shell Micro Credit Scheme, Women-in-Agriculture (WIA) programme, Delta Agricultural procurement Agency (Input distribution), Agricultural Development Project, and Agricultural Cooperative Societies. A lot of programmes have been implemented in the study area but have faded out due to lack of commitment on the part of the donors and interest by the beneficiaries. It is important to continually evaluate projects in order to ensure successful outcomes. Horton et. al (2003) noted that monitoring and evaluation were carried out to meet external accountability requirements. Governmental authorities and donors required information on how organizations used their resources and what results were being obtained.

\section{Attitude of Non-youth Leaders to agricultural Development Intervention Programmes}

The result in Table 1 showed that the non-youth leaders disagreed with the 5 positive statements and agreed with 4 negative statements. The respondents disagreed with only one negative statement. It could be summarised that the non-youth leaders have a negative attitude to the 5 agricultural development programmes.

The data on attitude of non-youth leaders to agricultural development programmes were analysed and presented in Table 1. 
TABLE 1: Attitude rating of non-youth leaders to agricultural development intervention programmes $(\mathrm{N}=58)$

\begin{tabular}{|c|c|c|c|c|}
\hline S/N & Statements & Total Score & $\bar{X} \mathrm{MAX}=4$ & Remarks \\
\hline+1 & $\begin{array}{l}\text { Agricultural development } \\
\text { programmes are necessary } \\
\text { for motivating youths to take } \\
\text { up agriculture }\end{array}$ & 72 & 1.36 & Disagree \\
\hline+2 & $\begin{array}{l}\text { Agricultural development } \\
\text { programmes help to } \\
\text { improve the skills of youth in } \\
\text { Agriculture }\end{array}$ & 75 & 1.40 & Disagree \\
\hline+3 & $\begin{array}{l}\text { Properly organized } \\
\text { agricultural development } \\
\text { programmes can help } \\
\text { improve the income of } \\
\text { youths }\end{array}$ & 120 & 2.26 & Disagree \\
\hline+4 & $\begin{array}{l}\text { Agricultural development } \\
\text { programmes are means of } \\
\text { introducing new techniques } \\
\text { and practices }\end{array}$ & 78 & 1.47 & Disagree \\
\hline+5 & $\begin{array}{l}\text { Agricultural development } \\
\text { programmes help to solve } \\
\text { the production problems of } \\
\text { rural youths }\end{array}$ & 113 & 2.13 & Disagree \\
\hline+6 & $\begin{array}{l}\text { Agricultural development } \\
\text { programmes caters for } \\
\text { selfish interest of } \\
\text { government officials }\end{array}$ & 56 & 1.06 & Agree \\
\hline+7 & $\begin{array}{l}\text { Agricultural development } \\
\text { programmes are meant for } \\
\text { youths who cannot secure } \\
\text { good jobs }\end{array}$ & 133 & 2.51 & Disagree \\
\hline+8 & $\begin{array}{l}\text { Agricultural development } \\
\text { programmes do not address } \\
\text { the felt needs of the youth }\end{array}$ & 75 & 1.40 & Agree \\
\hline+9 & $\begin{array}{l}\text { Agricultural development } \\
\text { programmes cannot bring } \\
\text { drastic socio-economic } \\
\text { changes on the youth }\end{array}$ & 108 & 2.04 & Agree \\
\hline+10 & $\begin{array}{l}\text { Government is not } \\
\text { committed to agricultural } \\
\text { development programmes }\end{array}$ & 56 & 1.06 & Agree \\
\hline
\end{tabular}


Journal of Agricultural Extension

Vol. 13 (2) December 2009

\section{Attitude of youth Leaders to Agricultural development Intervention Programmes}

The results in Table 2 showed that the youth leaders disagreed with the 5 positive and 5 negative statements. It could be concluded that the youth leaders have an outright negative attitude to the agricultural development programmess. The youth leaders appear to be more interested in the revenue that accrues to them as leaders than as farmers.

TABLE 2: Attitude rating of youth leaders to agricultural development intervention programmes

\begin{tabular}{|c|c|c|c|c|}
\hline$S / N$ & Statements & Total Score & $\bar{X} \mathrm{MAX}=4$ & Remark \\
\hline+1 & $\begin{array}{l}\text { Agricultural development } \\
\text { programmes are necessary } \\
\text { for motivating youths to take } \\
\text { up agriculture }\end{array}$ & 33 & 1.83 & Disagree \\
\hline+2 & $\begin{array}{l}\text { Agricultural development } \\
\text { programmes help to improve } \\
\text { the skills of youth in } \\
\text { agriculture }\end{array}$ & 44 & 2.83 & Disagree \\
\hline+3 & $\begin{array}{l}\text { Properly organized } \\
\text { agricultural development } \\
\text { programmes can help } \\
\text { improve the income of } \\
\text { youths }\end{array}$ & 35 & 1.94 & Disagree \\
\hline+4 & $\begin{array}{l}\text { Agricultural development } \\
\text { programmes are means of } \\
\text { introducing new techniques } \\
\text { and practices }\end{array}$ & 33 & 1.83 & Disagree \\
\hline+5 & $\begin{array}{l}\text { Agricultural development } \\
\text { programmes help to solve } \\
\text { the production problems of } \\
\text { rural youths }\end{array}$ & 36 & 2.00 & Disagree \\
\hline-6 & $\begin{array}{l}\text { Agricultural development } \\
\text {.programmes caters for } \\
\text { selfish interest of } \\
\text { government officials }\end{array}$ & 28 & 1.56 & Agree \\
\hline-7 & $\begin{array}{l}\text { Agricultural development } \\
\text { programmes is meant for the } \\
\text { youths who cannot secure } \\
\text { good jobs }\end{array}$ & 20 & 1.11 & Agree \\
\hline-8 & $\begin{array}{l}\text { Agricultural development } \\
\text { programmes do not address } \\
\text { the felt needs of the youth }\end{array}$ & 20 & 1.11 & Agree \\
\hline-9 & $\begin{array}{l}\text { Agricultural development } \\
\text { programmes cannot bring } \\
\text { drastic socio-economic } \\
\text { changes on the youth }\end{array}$ & 32 & 1.78 & Agree \\
\hline-10 & $\begin{array}{l}\text { Government is not } \\
\text { committed to agricultural } \\
\text { development programmes }\end{array}$ & 18 & 1.00 & Agree \\
\hline
\end{tabular}




\section{Comparison of Attitude Rating of Non-youth Leaders and Leaders}

The result showed that there was no significant difference between the mean attitude scores of youth leaders and non-leaders to agricultural development intervention programmes. The youths in the study area have negative attitude to agricultural development intervention programmes. This corroborates the view of Olaitan (1984) that most pupils have negative attitude to agriculture. He contended that the school with all its amenities and educated agriculturists had nothing to offer to develop the right attitude on the pupils.

The mean attitude scores of non-youth leaders and leaders were compared by the use of t-test (Table 3).

TABLE 3: Summary of t-test Analysis

\begin{tabular}{cccc}
\hline $\begin{array}{c}\text { Mean Non- youth } \\
\text { leaders }\end{array}$ & Mean Youth Leaders & t-cal & Sig. \\
\hline 1.67 & 1.66 & 0.05 & $P=0.05$ \\
\hline$(t=0.05, P>0.05)$ & & &
\end{tabular}

\section{Factor Militating Against Youth Involvement in Agriculture}

The results in Table 4 showed that the factors militating against youth involvement in agriculture were ack of basic infrastructure $(X=2.62)$, lack of modern agricultural equipment $(x=3.46)$, lack of credit facilities/subsidies $(X=2.99)$ and poor incentive/income $(X=3.00)$. The tong investment period $X=2.20$ ) and social and psychological effects of being called a farmer $(X=2.03)$ were not serious factors militating against youth involvement in agriculture. This finding contradicted that of Akinsanmi (1994) that many youths were being discouraged from agriculture because farming was meant for those who have not been educated or people who failed in other jobs. Nowadays, many influential and wealthy individuals now invest in agriculture.

The responses to the factors militating against youth involvement in agriculture were analysed by using a 4-point rating scale (Table 4). 
Journal of Agricultural Extension

Vol. 13 (2) December 2009

\begin{tabular}{|c|c|c|c|c|}
\hline $\mathbf{S} / \mathbf{N}$ & Factor & $\begin{array}{c}\text { Total } \\
\text { Scores }\end{array}$ & $\bar{X} \operatorname{MAX}=4$ & Remark \\
\hline 1. & Lack of basic infrastructure & 186 & 2.62 & Agree \\
\hline 2 & $\begin{array}{l}\text { Lack of modern agricultural } \\
\text { equipment }\end{array}$ & 246 & 3.46 & Agree \\
\hline 3 & $\begin{array}{l}\text { Long investment period in } \\
\text { agriculture }\end{array}$ & 156 & 2.20 & Disagree \\
\hline 4 & $\begin{array}{l}\text { Lack of land/land tenure } \\
\text { system }\end{array}$ & 237 & 3.34 & Agree \\
\hline 5 & $\begin{array}{l}\text { Social and psychological } \\
\text { effects of being called a } \\
\text { farmer }\end{array}$ & 144 & 2.03 & Disagree \\
\hline 6 & $\begin{array}{l}\text { Lack of credit } \\
\text { facilities/subsidies }\end{array}$ & 212 & 2.99 & Agree \\
\hline 7. & Poor incentives/income & 213 & 3.00 & Agree \\
\hline
\end{tabular}

\section{CONCLUSION}

The youth in the study area have negative attitude towards agricultural development interventions. Lack of basic infrastructure in rural areas, lack of modern agricultural equipment, lack of land/land tenure system, lack of credit facilities/subsidies, and poor incentives/income were the problems militating against youth involvement in agriculture. The much anticipated food sufficiency can only be achieved in the country if the youths are motivated to take up agriculture as a sustainable means of livelihood. This could be achieved by providing large tract of land for the youth, provision of credit facilities/ subsidies and rural infrastructure.

\section{REFERENCES}

Aknisanmi, O. (1994). Senior Secondary Agricultural Science. London: Longman

Horton, D. Alexaki, A. Bennett - Lartey, S., Bruce, K.N. et'al (2003). Evaluating Capacity Development: Experiences from Research and Development Organisations around the World. Netherlands :. ISNAR, CTA. IDRC and CRDI.

Olaitan, S.O. (1984). Agricultural Education in the Tropics: Methodology for Teaching Agriculture, London: Macmillan Publishers s

Ovwigho, B.O. (1985). Problems of Agricultural Programmess. The Nigerian Observer Thursday January 31, 1985, P;7

Ovwigho, B.O. (2007). Youth Mobilisation and the Need for Dialogue in a Conflict situation. $A$ Paper Delivered at a one Day Workshop Organised by the Ministry of Youths and Sports Development, Delta State, Asaba. 
Ovwigho, B.O. (2008). The Nigerian Youth: The Need for Responsible Fellowership. A Paper Delivered to selected Youths at the NYSC Orientation Camp Isele-Uku Delta State

Ovwgho, B.O. and Ifie, P.A. (2004). Principles of Youth Development: A Reference Manual for Developing Countries. Lagos: Excel Publishers.

Oxford Advanced Learner's Dictionary $7^{\text {th }}$ Edition

Rau, W.E. and Lindley W.I. (1985). Rural Youth: Some Broad Characteristics. In FAO (ed). Training for Agriculture and Rural Development Rome :FAO.

Swanson, B.E. and Claar, J.B. (1984). The History and Development of Agricultural Extension. In: Swanson, B.E. (ed). Agricultural Extension : A Reference Manual. Rome : FAO. pp 118. 